DOI: 10.21055/0370-1069-2020-4-92-98

УДК 616.98:578.2

А.Ю. Попова ${ }^{1,2}$, Е.Б. Ежлова ${ }^{1}$ Ю.В. Демина ${ }^{1}$, А.Н. Куличенко ${ }^{3}$, О.В. Малецкая ${ }^{3}$, А.Г. Рязанова ${ }^{3}$, И.В. Кузнецова ${ }^{3}$, О.А. Гнусарева ${ }^{3}$, М.Е. Михайлова ${ }^{3}$, О.В. Сирица ${ }^{3}$, Е.А. Манин ${ }^{3}$, С.А. Портенко ${ }^{4}$, Т.Ю. Красовская ${ }^{4}$ В.Е. Куклев ${ }^{4}$, Е.С. Казакова ${ }^{4}$, М.М. Данилевская ${ }^{5}$, М.В. Сафонова ${ }^{5}$, Н.В. Тельнова С.М. Иванова ${ }^{5}$, А.А. Лопатин ${ }^{5}$

\title{
МОБИЛЬНЫЕ КОМПЛЕКСЫ СПЭБ РОСПОТРЕБНАДЗОРА КАК ДЕЙСТВЕННЫЙ ИНСТРУМЕНТ ПРИ РЕАЛИЗАЦИИ МЕРОПРИЯТИИ ПО ПРОТИВОДЕЙСТВИЮ НОВОЙ КОРОНАВИРУСНОЙ ИНФЕКЦИИ COVID-19
}

\footnotetext{
${ }^{1}$ Федеральная служба по надзору в сфере зашиты прав потребителей и благополучия человека, Москва, Российская Федераиия; ${ }^{2}$ Российская медицинская академия непрерывного профессионального образования, Москва, Российская Федерация; ${ }^{3}$ ФКУЗ «Ставропольский научно-исследовательский противочумный институт», Ставрополь, Российская Федераиия; ${ }^{4}$ ФКУЗ «Российский научно-исследовательский противочумный институт «Микроб», Саратов, Российская Федераиия; ${ }^{5}$ ФКУЗ «Противочумный иентр», Москва, Российская Федерация
}

Для реализации оперативных мероприятий по противодействию COVID-19 в Российской Федерации с целью организации и проведения диагностических исследований активно задействованы мобильные комплексы специализированных противоэпидемических бригад (СПЭБ) Роспотребнадзора (на базе автошасси). Анализ деятельности мобильных СПЭБ в Москве и Махачкале в наиболее сложный период негативного развития ситуации, роста заболеваемости и недостаточной готовности лабораторных баз к массовым исследованиям позволил сформулировать основные принципы организации их работы в этот период: тактика опережающих действий, гибкость использования потенциала мобильных комплексов СПЭБ, контроль выполнения противоконтаминационных мероприятий на всех этапах ПЦР-анализа и развитие консультативно-методического (образовательного) направления деятельности специалистов бригад. Использование мобильных СПЭБ Роспотребнадзора в очередной раз продемонстрировало их значение в качестве универсального инструмента противодействия эпидемиям инфекционных болезней.

Ключевые слова: мобильный комплекс СПЭБ, COVID-19, лабораторная диагностика, ПЦР.

Корреспондирующий автор: Малецкая Ольга Викторовна, e-mail: stavnipchi@mail.ru.

Для цитирования: Попова А.Ю., Ежлова Е.Б., Демина Ю.В., Куличенко А.Н., Малецкая О.В., Рязанова А.Г., Кузнецова И.В., Гнусарева О.А., Михайлова М.Е., Сирица Ю.В., Манин Е.А., Портенко С.А., Красовская Т.Ю., Куклев В.Е., Казакова Е.С., Данилевская М.М., Сафонова М.В., Тельнова Н.В., Иванова С.М., Лопатин А.А. Мобильные комплексы СПЭБ Роспотребнадзора как действенный инструмент при реализации мероприятий по противодействию новой коронавирусной инфекции COVID-19. Проблемы особо опасных инфекций. 2020; 4:92-98. DOI: 10.21055/0370-1069-2020-4-92-98

Поступила 22.10.20. Принята к публ. 20.11.20

A.Yu. Popova ${ }^{1,2}$, E.B. Ezhlova ${ }^{1}$, Yu.V. Demina ${ }^{1}$, A.N. Kulichenko ${ }^{3}$, O.V. Maletskaya ${ }^{3}$, A.G. Ryazanova ${ }^{3}$, I.V. Kuznetsova ${ }^{3}$, O.A. Gnusareva ${ }^{3}$, M.E. Mikhailova ${ }^{3}$, Yu.V. Siritsa ${ }^{3}$, E.A. Manin ${ }^{3}$, S.A. Portenko ${ }^{4}$, T.Yu. Krasovskaya ${ }^{4}$, V.E. Kuklev ${ }^{4}$, E.S. Kazakova ${ }^{4}$, M.M. Danilevskaya ${ }^{5}$, M.V. Safonova ${ }^{5}$, N.V. Tel'nova ${ }^{5}$, S.M. Ivanova ${ }^{5}$, A.A. Lopatin ${ }^{5}$

\section{Mobile Complexes of the Specialized Anti-Epidemic Teams (SAET) of the Rospotrebnadzor as an Effective Tool in the Implementation of Measures to Counter New Coronavirus Infection COVID-19}

${ }^{1}$ Federal Service for Surveillance in the Sphere of Consumers Rights Protection and Human Welfare, Moscow, Russian Federation; ${ }^{2}$ Russian Medical Academy of Continuing Professional Education, Moscow, Russian Federation:

${ }^{3}$ Stavropol Research Anti-Plague Institute, Stavropol, Russian Federation;

${ }^{4}$ Russian Research Anti-Plague Institute "Microbe", Saratov, Russian Federation,

${ }^{5}$ Plague Control Center, Moscow, Russian Federation

Abstract. The mobile complexes of the specialized anti-epidemic teams (SAET) of the Rospotrebnadzor (mounted on the platform of auto chassis) have been actively involved in implementation of operational measures to counter COVID-19 in the Russian Federation, aimed at management and conducting of diagnostic studies. Analysis of the activities of mobile SAET in Moscow and Makhachkala made it possible to formulate the basic principles of organizing their work in the most difficult period of negative development of the situation, increasing incidence and insufficient readiness of laboratory bases for mass research: tactics of advance actions, flexibility in using the potential of SAET mobile complexes, monitoring over the implementation of anti-contamination measures at all stages of PCR analysis and the development of a consultative and methodological (training) aspects of activities of the team specialists. The use of mobile SAETs of the Rospotrebnadzor once again demonstrated their significance as a universal tool to counter epidemics of infectious diseases.

Key words: mobile complex of SAET, COVID-19, laboratory diagnostics, PCR.

Conflict of interest: The authors declare no conflict of interest.

Corresponding author: Olga V. Maletskaya, e-mail: stavnipchi@mail.ru.

Citation: Popova A.Yu., Ezhlova E.B., Demina Yu.V., Kulichenko A.N., Maletskaya O.V., Ryazanova A.G., Kuznetsova I.V., Gnusareva O.A., Mikhailova M.E., Siritsa Yu.V., Manin E.A., Portenko S.A., Krasovskaya T.Yu., Kuklev V.E., Kazakova E.S., Danilevskaya M.M., Safonova M.V., Tel'nova N.V., Ivanova S.M., Lopatin A.A. Mobile 
Complexes of the Specialized Anti-Epidemic Teams (SAET) of the Rospotrebnadzor as an Effective Tool in the Implementation of Measures to Counter New Coronavirus Infection COVID-19. Problemy Osobo Opasnykh Infektsii [Problems of Particularly Dangerous Infections]. 2020; 4:92-98. (In Russian). DOI: 10.21055/0370-1069-20204-92-98

Received 22.10.20. Accepted 20.11.20.

Popova A.Yu., ORCID: https://orcid.org/0000-0002-4315-5307 Kulichenko A.N., ORCID: https://orcid.org/0000-0002-9362-3949 Maletskaya O.V., ORCID: https://orcid.org/0000-0002-3003-4952 Kuznetsova I.V., ORCID: https://orcid.org/0000-0001-9513-0761 Siritsa Yu.V., ORCID: https://orcid.org/0000-0001-9442-6966

Сложившаяся в 2020 г. напряженная эпидемическая обстановка, связанная с распространением в Российской Федерации новой коронавирусной инфекции COVID-19 (вызванной вирусом тяжелого острого респираторного синдрома 2-го типа SARSCoV-2, Severe acute respiratory syndrome-related coronavirus 2), потребовала организации беспрецедентных мер предотвращения эпидемиологических последствий в условиях объявленной пандемии. Одной из первостепенных задач в комплексе противоэпидемических мероприятий являлось экстренное выявление больных COVID-19 и лиц с неманифестной формой заболевания, массовое обследование лиц, контактировавших с больными и/или прибывших из государств, неблагополучных по этой инфекции [1-3]. Для выполнения больших объемов исследований, требующих соблюдения усиленных мер по обеспечению биологической безопасности работ, задействованы мобильные комплексы специализированных противоэпидемических бригад Роспотребнадзора (МК СПЭБ) - автономно функционирующие формирования экстренного реагирования, укомплектованные современным диагностическим оборудованием. СПЭБ Роспотребнадзора ранее неоднократно использовались для решения задач по предупреждению и ликвидации чрезвычайных ситуаций в сфере санитарно-эпидемиологического благополучия населения, при проведении важных массовых мероприятий как на территории Российской Федерации, так и за ее пределами.

Поскольку первый и главный удар инфекции приняла на себя Москва, в рамках упреждающих действий по обеспечению необходимых объемов лабораторной диагностики COVID-19 на период экстренного перепрофилирования стационарной лабораторной базы ФКУЗ «Противочумный центр» Роспотребнадзора на массовые исследования и в соответствии с указанием Руководителя Федеральной службы по надзору в сфере защиты прав потребителей и благополучия человека, в Москву направлен мобильный комплекс СПЭБ первого поколения ФКУЗ «Ставропольский научно-исследовательский противочумный институт» Роспотребнадзора в составе четырех лабораторных модулей и группа высококвалифицированных специалистов, подготовленных к работе в условиях чрезвычайных ситуаций.

Работа СПЭБ на базе ФКУЗ «Противочумный центр». СПЭБ приступила к работе 15.03.2020. Все работы осуществлялись совместно со специалистами СПЭБ ФКУЗ РосНИПЧИ «Микроб» и специалистами ФКУЗ «Противочумный центр», в даль- нейшем - также со специалистами СПЭБ ФКУЗ «Волгоградский научно-исследовательский противочумный институт» и СПЭБ ФКУЗ «Ростовскийна-Дону противочумный институт». Перед СПЭБ поставлена задача по организации на базе лабораторий МК СПЭБ ПЦР-диагностики COVID-19 с целью обеспечения мощности молекулярно-генетических исследований до 1500 проб в сутки материала от больных и пациентов с подозрением на COVID-19 из медицинских организаций Москвы, а также секционного материала.

Всю работу СПЭБ в Москве можно условно разделить на четыре этапа.

I этап. Развертыввание СПЭБ. Организация работы. На первом этапе решены следующие первостепенные задачи:

- бригада СПЭБ Ставропольского противочумного института, в соответствии с планом работ, полностью укомплектована высококвалифицированными специалистами, лабораторным оборудованием, диагностическими препаратами, переносным информационно-коммуникационным оборудованием и другим расходным имуществом;

- адаптирован порядок функционирования лабораторий МК СПЭБ к работе на базе развертывания с учетом включения в состав бригад специалистов Противочумного центра и РосНИПЧИ «Микроб»;

- разработана схема движения проб исследуемого материала и персонала;

- адаптированы рабочие инструкции для каждого этапа лабораторной диагностики;

- обеспечена биологическая безопасность личного состава и окружающей среды;

- разработан порядок взаимодействия СПЭБ с другими организациями лабораторнодиагностической и лечебно-профилактической сети.

На выделенной территории ФКУЗ «Противочумный центр» в течение 6 ч проведено развертывание МК СПЭБ в составе четырех лабораторных модулей на базе автошасси: индикационная, бактериологическая, санитарно-гигиеническая лаборатории и лаборатория поддержки бактериологических исследований. Место дислокации модулей, маршруты движения ПБА и персонала обозначены как «зона строгого противоэпидемического режима», вход на территорию ограничен сигнальной лентой.

В помещениях здания Противочумного центра организованы:

- штаб для координации всей работы;

- прием и временное хранение транспортировочных контейнеров с пробами; 
- хранение расходных материалов и реагентов, санитарный пропускник, гардероб и помещение для отдыха сотрудников.

При участии Департамента здравоохранения города Москвы организованы и обеспечены необходимым техническим оборудованием 14 рабочих мест для регистрации поступающих проб в системе ЕМИАС и последующего внесения результатов исследований. Для проведения данной работы задействованы специалисты Противочумного центра, ФБУН НИИ дезинфектологии Роспотребнадзора, ФБУН ФНЦГ им. Ф.Ф. Эрисмана, ГБУ МФЦ города Москвы.

II этап. Выполнение на базе СПЭБ всего комплекса лабораторных исследований методом ПЦР. Материал для исследования в контейнерах, биксах или сумках-холодильниках передавали в лабораторию индикации (блок для работы с инфицированным материалом), где осуществляли разбор и кодирование, первичную подготовку и обеззараживание проб для последующего исследования методом ПЦР в режиме реального времени. Для проведения молекулярно-генетических исследований перепрофилированы бактериологическая и санитарногигиеническая лаборатории, а также блок для работы с обеззараженным материалом индикационной лаборатории. При этом в бактериологической и санитарно-гигиенической лабораториях оборудованы рабочие места по экстракции нуклеиновых кислот из обеззараженного материала и рабочие места по проведению обратной транскрипции и ПЦР, на базе индикационной лаборатории - рабочее место по проведению обратной транскрипции и ПЦР.

Для проведения ПЦР в реальном времени использовали амплификаторы роторного типа Rotor-Gene Q (QIAGEN GmbH, Германия): два - в индикационной лаборатории (блок для работы с обеззараженным материалом) и два - в санитарно-гигиенической лаборатории. Дополнительно индикационная, бактериологическая и санитарно-гигиеническая лаборатории оснащены амплификатором планшетного типа CFX 96 (BioRad, CША) и термоциклерами «Терцик» (ООО «НПО ДНК-технология», Россия) для проведения реакции обратной транскрипции.

Исходно СПЭБ обеспечена наборами реагентов, расходными материалами, средствами индивидуальной защиты, дезинфицирующими средствами для работы в течение одной недели. В дальнейшем по мере необходимости расходными материалами и дополнительным оборудованием обеспечивал ФКУЗ «Противочумный центр» Роспотребнадзора.

Для защиты персонала и окружающей среды в лабораторных модулях МК СПЭБ задействованы типовые инженерно-технические системы биологической безопасности уровня BSL 3, включающие:

- автономную приточную и вытяжную системы вентиляции, оборудованные фильтрами очистки воздуха класса НЕРА и системой постоянного контроля и поддержания отрицательного давления в «заразной» зоне каждой мобильной лаборатории;
- санпропускники с душем и взаимоблокировкой дверей;

- бактерицидные облучатели рециркуляторного и открытого типа;

- БМБ II и III класса для обеспечения безопасности работ с инфицированным материалом.

Обеззараживание отходов осуществляли в лаборатории поддержки бактериологических исследований методом автоклавирования.

Работа проводилась в круглосуточном трехсменном режиме без выходных, среднесуточная мощность составила 750 исследований.

Полученные результаты ПЦР (внутренние протоколы) на бумажных носителях передавались в штаб, где формировалась единая база данных результатов исследований. Далее информация размещалась в Единой медицинской информационноаналитической системе г. Москвы (ЕМИАС).

За период работы с 15.03.2020 по 20.03.2020 в МК СПЭБ проведено 3663 исследования методом ПЦР, генетические маркеры коронавируса SARSCoV-2 детектированы в 162 пробах клинического материала.

В связи с резким увеличением объема поступающего на исследование материала на фоне ухудшения эпидемиологической обстановки, перепрофилированием стационарных лабораторий Противочумного центра, включением в единую бригаду специалистов других противочумных институтов и учреждений Роспотребнадзора, с 21.03.2020 алгоритм использования МК СПЭБ изменен.

III этап. Выполнение на базе модулей СПЭБ этапов выделения РНК и ПЦР с проведением пробоподготовки на стационарной базе ФКУЗ «Противочумный иентр» Роспотребнадзора. С 21.03.2020 по 04.04.2020 с целью обеспечения биологической безопасности и деконтаминационного режима этапы разбора, пробоподготовки, обеззараживания материала и выделения РНК осуществляли на стационарной базе ФКУЗ «Противочумный центр». Работу с необеззараженным материалом проводили в специализированном блоке максимальной защиты Центра, далее обеззараженный материал поступал через передаточный шлюз в оборудованные стационарные помещения, в которых организованы рабочие места для проведения экстракции РНК из биологического материала. В МК СПЭБ проводили постановку обратной транскрипции и ПЦР. Для проведения ПЦР на данном этапе привлекались и сотрудники консультационно-диагностического центра ФБУН «Московский научно-исследовательский институт эпидемиологии и микробиологии им. Г.Н. Габричевского». Всего за данный период исследовано 21530 проб биологического материала, из них в 1218 пробах выявлена РНК коронавируса SARS-CoV-2. Среднесуточная мощность лабораторий МК СПЭБ, с учетом частичного задействования стационарной лабораторной базы Противочумного центра, составила 1500 проб. 
IV этап. Резервирование мощностей мобильных модулей СПЭБ и организация работы всех специалистов на стачионарной базе Противочумного иентра. С 04.04.2020 все этапы лабораторной диагностики осуществлялись в стационарных помещениях Противочумного центра. Движение материала организовано с соблюдением принципов поточности с территориальным разобщением каждого этапа ПЦР-анализа.

Благодаря увеличению числа специалистов и организации работ в трехсменном режиме мощность лаборатории увеличилась до 3000-3500 проб в сутки. Повышению производительности лаборатории также способствовал переход с ручного выделения нуклеиновых кислот из биологического материала на экстракцию с помощью шести автоматических станций KingFisher (Thermo Fisher Scientific, США), позволивший увеличить пропускную способность участка выделения нуклеиновых кислот.

Всего за период с 15.03.2020 по 04.04.2020 (21 день) проведено 25193 исследования клинического и аутопсийного материала методом ПЦР. В работе объединенной бригады приняли участие 11 специалистов Противочумного центра, 15 - Ставропольского НИПЧИ, 32 - РосНИПЧИ «Микроб», 22 - Ростовского-на-Дону НИПЧИ, 12 - Волгоградского НИПЧИ, 5 - ФБУН МНИЭМ им. Г.Н. Габричевского. Всего в проведении лабораторных исследований на новую коронавирусную инфекцию методом ПЦР на базе ФКУЗ «Противочумный центр» с 15.03.2020 по 01.09.2020 при посменной работе задействовано более 250 человек из 7 учреждений Роспотребнадзора: 23 специалиста Противочумного центра, 29 - Став- ропольского НИПЧИ, 71 - РосНИПЧИ «Микроб», 92 - Ростовского-на-Дону НИПЧИ, $31-$ Волгоградского НИПЧИ, 13 - ФБУН МНИЭМ им. Г.Н. Габричевского, 3 - ФБУН ЦНИИ эпидемиологии. За данный период работы проведено более 195 тыс. исследований клинического и аутопсийного материала методом ПЦР, получено более 50 тыс. положительных результатов (рис. 1).

Таким образом, организация лабораторной диагностики COVID-19 на базе лабораторий МК СПЭБ Роспотребнадзора позволила выполнять до 750 исследований методом ПЦР в сутки. Гибкий алгоритм работы, предусматривающий динамичное профильное задействование лабораторий МК СПЭБ и стационарных лабораторий Центра, позволил увеличить мощность до 3500 исследований в сутки.

Работа специалистов СПЭБ ФКУЗ «Ставропольский научно-исследовательский противочумный институт» в Республике Дагестан. В апреле 2020 г. в связи с серьезным осложнением эпидемической ситуации по COVID-19 в Республике Дагестан с целью оказания помощи в организации и проведении диагностических исследований в республику в соответствии с письмом руководителя Роспотребнадзора от 23.04.2020 № 02/7817-2020-26 направлена группа из пяти специалистов СПЭБ ФКУЗ «Ставропольский научно-исследовательский противочумный институт». Группа работала на базе ФКУЗ «Дагестанская противочумная станция» (Махачкала) с 19.04.2020 по 19.05.2020. Специалисты СПЭБ осуществляли все этапы ПЦР-анализа. Организован и ежедневно производился отбор респираторных мазков у лиц по показаниям.
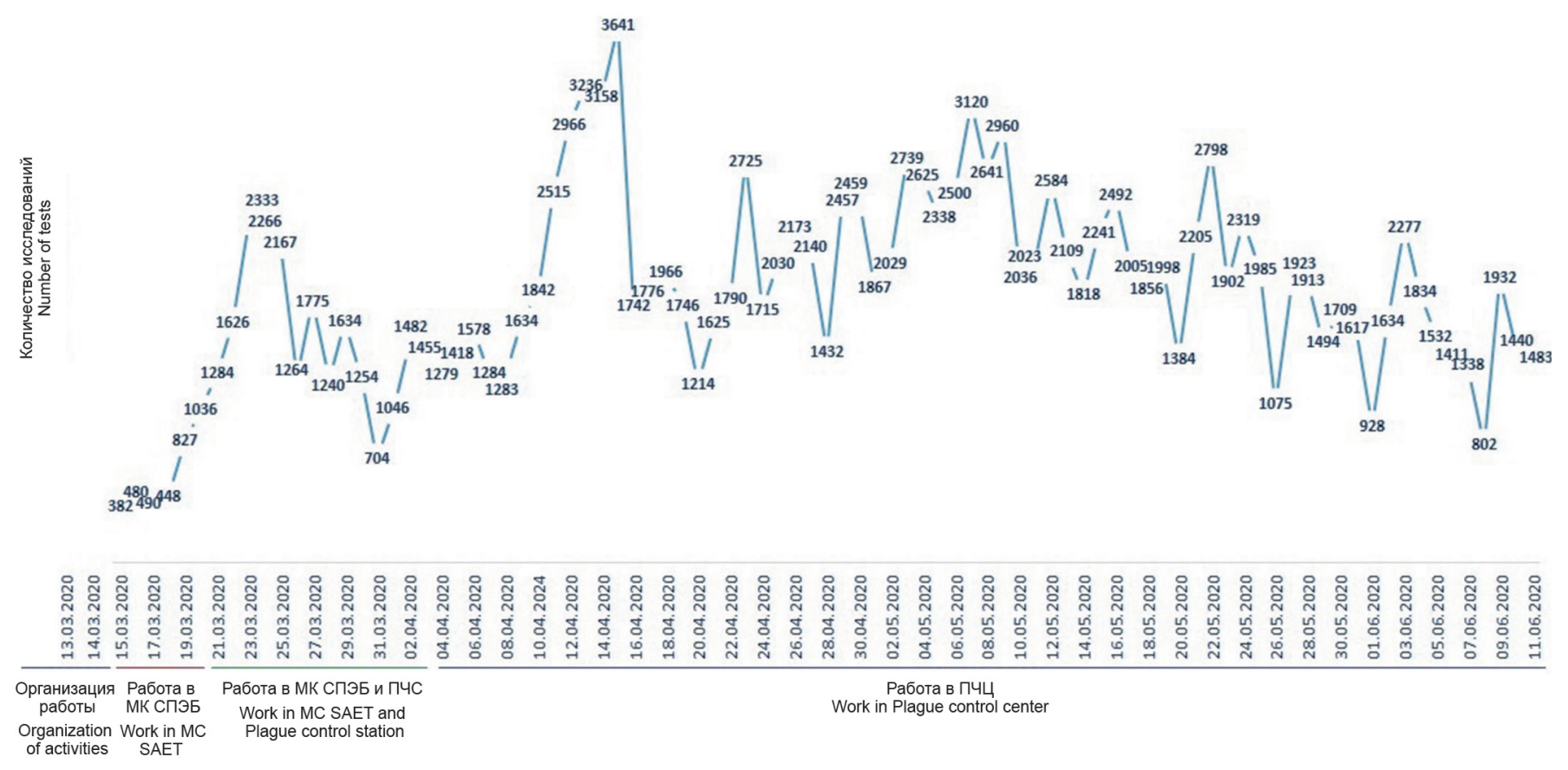

Рис. 1. Количество исследований (ПЦР-анализ) по диагностике COVID-19, выполненных на базе ФКУз «Противочумный центр» Роспотребнадзора в марте-июне 2020 г.

Fig. 1. The number of studies (PCR analysis) for the diagnosis of COVID-19, performed at the premises of Plague Control Center in March June 2020 
В связи с дальнейшим ухудшением ситуации по новой коронавирусной инфекции в Республике Дагестан в апреле-мае 2020 г., значительным ослаблением потенциала местной лабораторной службы из-за заболевания COVID-19 сотрудников учреждений Роспотребнадзора, в соответствии с приказом руководителя Роспотребнадзора от 20.05.2020 № 278 в Махачкалу направлен МК СПЭБ ФКУЗ «Ставропольский научно-исследовательский противочумный институт» второго поколения в составе двух лабораторий на автошасси: индикационной и бактериологической.

Работа на базе мобильных комплексов СПЭБ в Республике Дагестан осуществлялась в период с 20.05.2020 по 16.06.2020 с учетом опыта работы в Москве. Однако перед СПЭБ поставлен более широкий круг задач, включающий, кроме организации и проведения лабораторной диагностики новой коронавирусной инфекции, следующие мероприятия:

- проведение инструктажей сотрудников медицинских учреждений Республики Дагестан по соблюдению режима безопасности работ с клиническим материалом и при проведении лабораторной диагностики новой коронавирусной инфекции;

- обучение специалистов учреждений Роспотребнадзора Республики Дагестан диагностике COVID-19 методом ПЦР;

- оказание консультативно-методической помощи медицинским учреждениям Республики Дагестан по организации лабораторной диагностики COVID-19.

Всего задействованы 14 сотрудников ФКУЗ «Ставропольский научно-исследовательский противочумный институт», включая инженеров. Бригада оснащена двумя линиями оборудования для ПЦРисследований с детекцией результатов в формате реального времени, диагностическими наборами, расходными материалами, средствами индивидуальной защиты, дезинфектантами в полном объеме.
МК СПЭБ развернут на территории ФБУЗ «Центр гигиены и эпидемиологии в Республике Дагестан» (Махачкала). В индикационной лаборатории МК СПЭБ проводились разбор, кодировка, обеззараживание проб клинического материала, работа первой ПЦР-линии (экстракция РНК, обратная транскрипция, ПЦР), в бактериологической лаборатории МК СПЭБ функционировала вторая линия ПЦР. Специалисты СПЭБ также осуществляли диагностические исследования на стационарной базе бактериологической лаборатории ФБУЗ «Центр гигиены и эпидемиологии в Республике Дагестан», дополнительно оснащенной вспомогательным оборудованием СПЭБ, и задействованы на этапах выделения РНК, обратной транскрипции, ПЦР.

Диагностическая работа. За период с 20.04.2020 по 18.05.2020 специалистами СПЭБ исследовано 6026 проб клинического материала, получено 1946 положительных результатов, из них 1912 - первично положительных. Среднее количество исследований составляло 200 проб в день, доля первичных положительных результатов в среднем равнялась $31,42 \%$, в отдельные дни достигая 45-57 \% (рис. 2). За данный период количество исследований СПЭБ составило $22 \%$ от общего числа анализов по диагностике COVID-19 в Республике Дагестан, доля положительных результатов - $58 \%$ от совокупного количества полученных положительных тестов в республике.

В период с 24.05.2020 по 16.06.2020 специалистами СПЭБ в лабораториях МК СПЭБ и бактериологической лаборатории ФБУЗ «Центр гигиены и эпидемиологии в Республике Дагестан» исследовано 14979 проб клинического материала, получено 1600 положительных результатов. По сравнению с периодом работы с 20.04.2020 по 18.05.2020, при возросшем более чем в 3 раза количестве исследований в день (в среднем свыше 600 тестов в день), доля полученных положительных результатов уменьшилась втрое, составляя в среднем 10,73 \% (рис. 3 ).

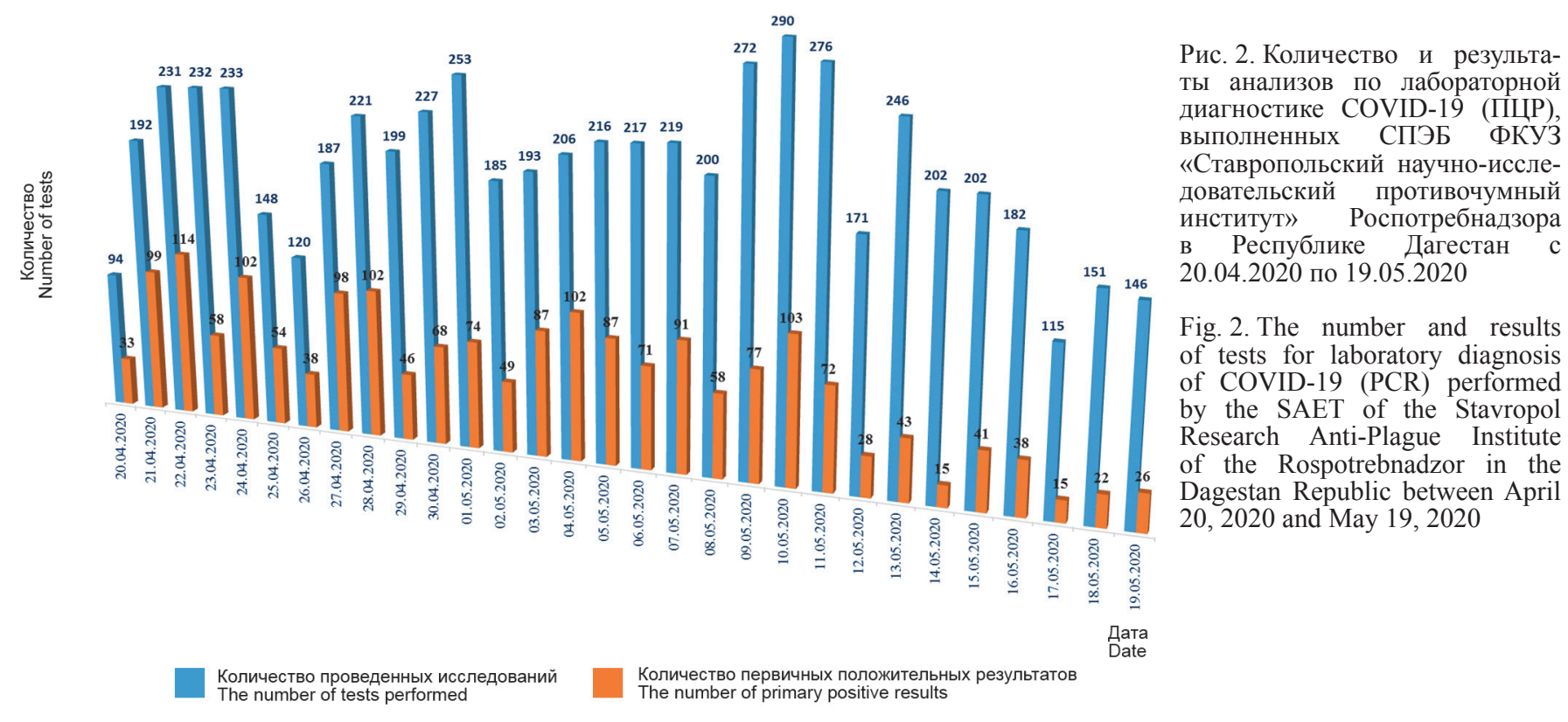


Кроме первичной ПЦР-диагностики COVID-19, СПЭБ осуществляла функции референс-лаборатории по верификации результатов исследований, проведенных в $\mathrm{OOO}$ «Единая клинико-диагностическая лаборатория» (Буйнакск), лабораторных отделениях мобильного многопрофильного полевого госпиталя воинской части № 74814 (Буйнакск) и мобильного многопрофильного полевого госпиталя, развернутого в н.п. Ботлих.

Всего за весь период работы с 20.04.2020 по 16.06.2020 специалистами СПЭБ исследовано 21005 проб клинического материала, получено 3546 положительных результатов. Количество анализов, проведенных СПЭБ, составило $19 \%$ от общего числа исследований по ПЦР-диагностике новой коронавирусной инфекции в Республике Дагестан за данный период, доля положительных результатов - 54 \%.

Также оказана консультативно-методическая помощь с проведением обучающих занятий для персонала четырех организаций Роспотребнадзора и четырех учреждений Минздрава Республики Дагестан (Махачкала, Буйнакск, Кизляр). Проведен инструктаж по соблюдению режима безопасности работ с клиническим материалом при проведении лабораторной диагностики новой коронавирусной инфекции, обучение методикам отбора респираторных мазков, разбора, пробоподготовки и обеззараживания проб клинического материала, экстракции РНК, проведения реакции обратной транскрипции, постановки ПЦР и интерпретации полученных результатов при ПЦР-диагностике COVID-19.

Таким образом, СПЭБ Роспотребнадзора выполнила не только поставленные задачи по лабораторной диагностике опасной инфекционной болезни, но и задачи по обучению специалистов республики методам выявления нуклеиновых кислот вируса SARS-CoV-2 с помощью ПЦР, организации работ и соблюдению требований режима биологической безопасности.

Работа мобильных комплексов СПЭБ Роспотребнадзора (на базе автошасси) при реализации мероприятий по противодействию новой коронавирусной инфекции COVID-19 в Москве и Махачкале осуществлялась в наиболее сложный период негативного развития ситуации, роста заболеваемости и недостаточной готовности лабораторных баз. Во всех случаях использованы форматы как автономного функционирования, так и во взаимодействии со стационарными лабораториями.

Анализ деятельности СПЭБ позволяет сформулировать основные принципы организации их работы в этот период:

1. Тактика опережающих действий на основе прогноза ситуации в конкретном регионе, расчета потребности в кадровых и материальных ресурсах на основе накопленного опыта работы СПЭБ при крупных вспышках и массовых обследованиях.

2. Гибкая тактика использования потенциала мобильных комплексов СПЭБ: в режиме автономной работы и во взаимодействии со стационарными лабораториями учреждений Роспотребнадзора.

3. Дифференцированный подход к организации каждого этапа с целью обеспечения максимальной эффективности и производительности работ.

4. Оперативная и эффективная организация работы объединенных бригад специалистов из различных учреждений Роспотребнадзора за счет унифицированной структуры МК СПЭБ.

5. Усиленный контроль и анализ данных на этапе учета и выдачи результатов ПЦР-исследования с целью правильной интерпретации ПЦР и исключения выдачи ложноположительных ответов, риск получения которых возрастает при больших объемах тестирования.

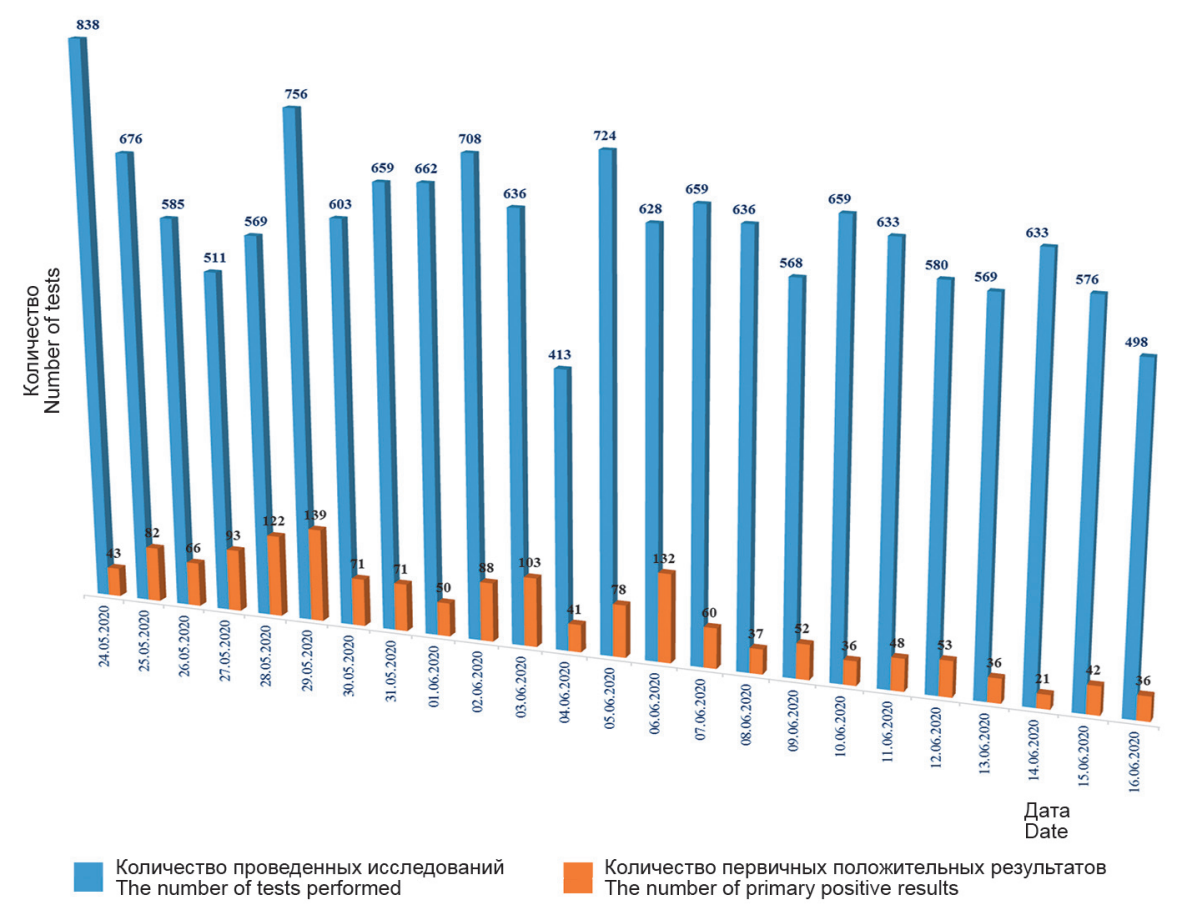

Рис. 3. Количество и результаты анализов по лабораторной диагностике COVID-19 (ПЦР), выполненных СПЭБ ФКУЗ «Ставропольский научноисследовательский противочумный институт» Роспотребнадзора в Республике Дагестан с 24.05.2020 по 16.06.2020

Fig. 3. The number and results of tests for laboratory diagnosis of COVID-19 (PCR) performed by the SAET of Stavropol Research Anti-Plague Institute in the Dagestan Republic between May 24, 2020 and June 16, 2020 
6. Усиленный контроль деконтаминационных мероприятий на этапах выделения нуклеиновых кислот, проведения обратной транскрипции и ПЦР в соответствии с действующими нормативнометодическими документами («контроль контроля») для обеспечения бесперебойной работы лабораторий в условиях высокой поточности.

7. Дальнейшее развитие консультативно-методического (образовательного) направления деятельности специалистов бригад как важного инструмента повышения уровня диагностических исследований в регионе и инструмента межведомственного взаимодействия.

Тактика эпидемиологического мониторинга COVID-19 в Российской Федерации, основанная на поэтапном расширении сети диагностических лабораторий, тотальном контроле точности лабораторной диагностики на первых этапах пандемии, обеспечение лабораторных баз отечественными лабораторными реагентами способствовали высокому качественному и количественному уровню диагностики, своевременному выявлению бессимптомных форм.

Очевидно, что именно современные научнометодические подходы к решению этой проблемы, полноценное использование имеющейся технологической базы позволили добиться необходимых результатов по защите населения Российской Федерации от новой коронавирусной инфекции COVID-19.

Использование мобильных СПЭБ Роспотребнадзора в очередной раз продемонстрировало их роль в качестве универсального инструмента противодействия эпидемиям инфекций как бактериальной, так и вирусной природы.

Конфликт интересов. Авторы подтверждают отсутствие конфликта финансовых/нефинансовых интересов, связанных с написанием статьи.

\section{Список литературы}

1. Федеральная служба по надзору в сфере защиты прав потребителей и благополучия человека. COVID-19 коронавиpyc. Информация для граждан. [Электронный ресурс]. URL: https://www.rospotrebnadzor.ru/about/info/news time/news details. php?ELEMENT_ID=13566 (дата обращения 14.10.2020).

2. Кутырев В.В., Попова А.Ю., Смоленский В.Ю., Ежлова Е.Б., Демина Ю.В., Сафронов В.А., Карнаухов И.Г., Иванова А.В., Щербакова С.А. Эпидемиологические особенности новой коронавирусной инфекции (COVID-19). Сообщение 1: Модели реализации профилактических и противоэпидемических мероприятий. Проблемы особо опасных инфекиий. 2020; 1:6-13. DOI: 10.21055/0370-1069-2020-1-6-13.

3. Кутырев В.В., Попова А.Ю., Смоленский В.Ю., Ежлова Е.Б., Демина Ю.В., Сафронов В.А., Карнаухов И.Г., Иванова А.В., Щербакова С.А. Эпидемиологические особенности новой коро- навирусной инфекции (COVID-19). Сообщение 2: Особенности течения эпидемического процесса COVID-19 во взаимосвязи с проводимыми противоэпидемическими мероприятиями в мире и Российской Федерации. Проблемы особо опасных инфекиий. 2020; 2:6-12. DOI: 10.21055/0370-1069-2020-2-6-12.

\section{References}

1. [Federal Service for Surveillance in the Sphere of Consumers Rights Protection and Human Welfare. COVID-19 Coronavirus. Information for citizens]. (Cited 15 June 2020). [Internet]. Available from: https://www.rospotrebnadzor.ru/about/info/news time/news details.php?ELEMENT ID=13566.

2. Kutyrev V.V., Popova A.Yu., Smolensky V.Yu., Ezhlova E.B., Demina Yu.V., Safronov V.A., Karnaukhov I.G., Ivanova A.V., Shcherbakova S.A. [Epidemiological Features of New Coronavirus Infection (COVID-19). Communication 1: Modes of Implementation of Preventive and Anti-Epidemic Measures]. Problemy Osobo Opasnykh Infektsii [Problems of Particularly Dangerous Infections]. 2020; 1:6-13. DOI: 10.21055/0370-1069-2020-1-6-13.

3. Kutyrev V.V., Popova A.Yu., Smolensky V.Yu., Ezhlova E.B., Demina Yu.V., Safronov V.A., Karnaukhov I.G., Ivanova A.V., Shcherbakova S.A. [Epidemiological Features of New Coronavirus Infection (COVID-2019). Communication 2: Peculiarities of epidemic process development in conjunction with performed anti-epidemic measures around the world and in the Russian Federation]. Problemy Osobo Opasnykh Infektsii [Problems of Particularly Dangerous Infections]. 2020; 2:6-12. DOI: 10.21055/0370-1069-2020-2-6-12.

Authors:

Popova A.Yu. Federal Service for Surveillance in the Sphere of Consumers Rights Protection and Human Welfare; 18, Bld. 5 and 7 , Vadkovsky Pereulok, Moscow, 127994, Russian Federation. Russian Medical Academy of Continuing Professional Education; 2/1, Barrikadnaya St., Moscow, 125993, Russian Federation.

Ezhlova E.B., Demina Yu.V.Federal Service for Surveillance in the Sphere of Consumers Rights Protection and Human Welfare. 18, Bld. 5 and 7, Vadkovsky Pereulok, Moscow, 127994, Russian Federation.

Kulichenko A.N. Maletskava O.V. Ryazanova A.G., Kuznetsova I.V., Gnusareva O.A., Mikhailova M.E., Siritsa Yu.V., Manin E.A. Stavropol Research Anti-Plague Institute. 13-15, Sovetskaya St., Stavropol, 355035, Russian Federation. E-mail: stavnipchi@mail.ru.

Portenko S.A., Krasovskaya T.Yu., Kuklev V.E., Kazakova E.S. Russian Research Anti-Plague Institute "Microbe". 46, Universitetskaya St., Saratov, 410005, Russian Federation. E-mail: rusrapi@microbe.ru.

Danilevskaya M.M., Safonova M.V., Tel'nova N.V., Ivanova S.M., Lopatin A.A. Plague Control Center. 4, Musorgskogo St., Moscow, 127490, Russian Federation. E-mail: protivochym@nln.ru.

\section{Об авторах:}

Попова А.Ю. Федеральная служба по надзору в сфере защиты прав потребителей и благополучия человека; Российская Федерашия, 127994 Москва, Вадковский переулок, дом 18, строение 5 и 7. Российская медицинская академия непрерывного профессионального образования; Российская Федерация, 125993, Москва, ул. Баррикадная, 2/1.

Ежлова Е.Б., Демина Ю.В. Федеральная служба по надзору в сфере защиты прав потребителей и благополучия человека. Российская Федерация, 127994, Москва, Вадковский переулок, дом 18, строение 5 и 7.

Куличенко А.Н., Малеикая О.В., Рязанова А.Г., Кузнеиова И.В., Гнусарева О.А., Михайлова М.Е., Сирица Ю.В., Манин Е.А. Ставропольский научно-исследовательский противочумный институт. Российская Федерация, 355035, Ставрополь, ул. Советская, 13-15. E-mail: stavnipchi@mail.ru.

Портенко С.А., Красовская Т.Ю., Куклев В.Е., Казакова Е.С. Российский научно-исследовательский противочумный институт «Микроб».Российская Федерация, 410005, Саратов, ул. Университетская, 46. E-mail: rusrapi@microbe.ru.

Данилевская М.М., Сафонова М.В., Тельнова Н.В., Иванова С.М., Лопатин А.А. Противочумный центр. Российская Федерация, 127490 , Москва, ул. Мусоргского, 4. E-mail: protivochym@nln.ru. 